\title{
Exploring Traditions of Identity Theory for Human Resource Development (HRD)
}

\section{Introduction}

The question of who is developed by HRD might appear self-evident. However, the answer becomes less certain when one seeks to understand how the individual changes through HRD activities and how these changes in turn shape what they do and how others respond to them. Such concerns are of central interest to the study of identity, a field that sees the question of who someone 'is', and indeed is not, as an important contributor to the personal and interpersonal dynamics of organisational life. Many of those engaged in identity scholarship would readily declare themselves to understand identity as a socially constructed phenomenon. Beyond this, however, contrasting research traditions adopt different positions on what constitutes an identity, where it emanates from, and how it might be known. Such variety means identity offers a potentially fruitful series of frameworks for exploring the nature, as well as the effect, of HRD on the individual and the workplace. Unlocking this potential, however, requires a firm understanding of the perspectives from which identity is described and the processes through which it is sustained and evolves.

Many HRD texts allude to the centrality of identity for HRD but rarely to theories of identity. Yet HRD, as efforts to direct and (re)position identities and behaviour through training and other activities, is a field replete with "tensions and contradictions" (McGuire \& Garavan 2013, p. 1) that we characterise through contrasting emphases upon the Human Resource Development, and Human Resource Development. Taking these in turn, the chapter teases out the identity issues embedded in these literatures, taking time to consider both individual and organisational level HRD processes. We then examine how three distinct identity perspectives: social identity, identity 
work and discourse and identity, might relate to these concerns before concluding the chapter with some questions that might inform the future trajectory of identity studies in Human Resource Development.

\section{Human Resource Development}

Laying emphasis upon the 'resource' aspect of HRD, Human Resource Development (HResource $\mathrm{D})$ positions individuals as a personal, organisational or societal resource focussed on individual, organisational or national performance (Holton \& Yamkovenko, 2008). As "human capital is created by changing individuals" Coleman (1998 in Holton \& Yamkovenko, 2008, p. 276), identity is implicated in the drive to (re)produce employees who meet the needs of productivity. Similarly, from an economic value perspective, the social capital of an organisation (which includes social relations and identities) is seen as a resource which can, amongst other outcomes, "reduce transaction costs" (Arregle, Hitt, Sirmon \& Very, 2007, p. 73).

\section{Individual Level HResourceD}

Issues of identity as a resource are articulated at individual level HRD through an instrumental view of self-reflection and self-development. This level includes individual developmental foci of self-efficacy, self-esteem (Allameh, Naftchali, Pool and Davoodi, 2012), self-concept (Day \& Harrison, 2007), personal change and human capital. All of the aforementioned relate to the subjectivity of the individual and comprise HResource D considerations in the form of mentoring, counselling and career guidance. 
The way identity is managed by the individual, and "forms a trajectory of development" (Giddens, 1991, p. 75), relates also to the changing nature of careers, particularly the self-guided development considered necessary for 'protean' or 'boundaryless' careers, where “people are free to (re)invent themselves periodically" (Hoyer \& Steyaert, 2015, p. 1838). This is encapsulated in the rhetoric of employability - which is both the development of the self as an identity project (Giddens, 1991) and yet still part of the resource rhetoric of $\mathrm{H}$ Resource $\mathrm{D}$ where identity is a marketable commodity.

\section{Organisational Level HResourceD}

Where HResourceD is concerned with crafting identities in the service of organisational performance and profit, developing social identities becomes a function of the HRD process. This is both as soft HRD - for example where HRD practices encourage employees to "develop a similar worldview and forge a shared identity" (McGuire \& Garavan, 2013, p. 2), or as harder HRD strategies with elements of coerced identity where employees may be "required to attach themselves" to a shared identity (Riach \& Loretto, 2009, p. 105). In either soft or hard approaches to human resource development, there exists scarce exploration or explanation of the different identity concepts at play within HRD and what processes might be employed to explore identity.

As an example of identity's potential, we see that organisational development and organisational performance literature focuses in the main on a resource based view of HResourceD. As subjectivity is constituted in relation to market value as a resource, through controlling or managing employees' identities, questions arise of how group identifications may influence reactions to organisational HRD efforts. Group influences might include how identity status 
differences between groups may serve to limit identities, including what people can be and become (Luthans, Vogelgsang \& Lester, 2006), and the identity work associated with this.

\section{Human Resource Development}

Perhaps unsurprisingly given its attempts to extract value by controlling, managing and even coercing identities HResourceD generates resistance, both at social identity level (union resistance to HRD: Garrick, 1998) and from those labelled 'resistant to change' (Carter, Howell \& Schied, 1999; Perriton, 2005). Human Resource Development (HumanRD), therefore, takes a contrasting emancipatory turn towards "the potential of human consciousness to reflect critically upon such oppressive practices" (Alvesson \& Wilmott, 1996, p. 13). This human-centred approach is often termed 'Critical HRD' (CHRD) and broadens the scope of the HRD gaze to include elements such as environmental concerns, cultural liberty (Devadas Silong \& Krauss, 2011), poverty and human rights and intends a foregrounding of structures of inequality and a recognition of hegemony. CHRD is, then, concerned with "the careful and reflective examination of ... constructions of identity" (Gedro, Collins \& Rocco, 2014, p. 529).

\section{Individual Level HumanRD}

For some scholars, to be 'human' is to be individual and unique (McGuire, Garavan, O'Donnell \& Watson, 2007, p. 2), valuing diversity and complexity of identities rather than the 'illusion of homogenous identities' (Fenwick, 2004, p. 198). Through an emphasis on human dignity and individual freedom from oppression, personal identity work within and beyond organisations is acknowledged. In including the dignity of identity, human dignity is "dependant on the subject's self-image" (Nordenfelt, 2004, p. 69). At an individual level this means that work as an identity 
resource can be drawn upon by those both in work and those "outwith the labour force" (Riach \& Loretto, 2009, p. 106).

\section{Organisational Level HumanRD}

HumanRD also retains a workplace context for emancipatory identity development. Fenwick (2005, p. 226) for instance anchors CHRD in the workplace by focusing on "social justice in the workplace", "organisational "undiscussables", "organisational democracy" and "feminist workplace studies". Similarly, Baek and Kim (2014) consider that stakeholder-based HRD "enhances the value of social responsibilities of corporations" (p. 499). Environmental issues are also emerging as Green HRD (Scully-Russ, 2015) seeks to develop frameworks that might answer the exhortation to 're-educate' (McGuire, 2014) about environmental issues in the workplace.

Identity is rarely explicitly considered in organisational approaches. For instance, an organisational-level resource-based view (HResource D) is often seen as being in conflict with HumanRD values, such as social justice (Johnsen \& Gudmand-Hoyer, 2010, p. 332) and has led to claims that within HRD "there has been considerable reluctance to deal with issues of diversity" (McGuire \& Garavan, 2013, p. 3). Exceptions include: Collins, McFadden, Rocco \& Mathis's (2015) consideration of LGB identity and HRD, and Byrd's (2014) consideration of the intersectionality of identities. Certainly, for HRD, identity is an important consideration when addressing organisationally-enacted issues such as the 'glass ceiling'.

The remainder of the chapter elaborates upon a developing understanding of HRD as facilitated through an identity focus. The selected identity perspectives are social identity, identity work, and 
discourse and identity. Each perspective contributes to an overall proposition that identity has the potential to advance understanding of the HResource D/ HumanRD field.

\section{Social Identity and Human Resource Development}

With exceptions (see Muir, 2014), Social identity (SI) research has attracted little attention from HRD practitioners. Consequently, before considering whether SI knowledge might improve the design of HRD initiatives, we examine briefly the core features of social identity. Social identity is concerned with those aspects of how we describe ourselves which derive from our membership of important groups (Tajfel, 1978). An SI is an emotional, self-defining attachment to a particular group (for example, a work-group, an organisation, a profession), which provides the individual and its other members with self-esteem and a collective status, as well as feelings of belonging, certainty and achievement. For an SI to develop, the aims and ways of behaving displayed by a specific group become internalised so that they contribute to how the person sees his/her self. An SI only becomes salient in a particular situation, for example, where the group's status is threatened, the person's immersion in their individual identity shifts to their group identity (Oakes, 1987). In a process called depersonalisation, this focus on the person's group identity means that the welfare of the group is put above their personal interests.

An acquired social identity does not necessarily remain permanent, nor will individual workers identify with every group they join. Rather, individuals seek a positive social identity by comparing themselves to others in interactions. How desirable a specific SI is regarded will depend on the person's judgement of the relative status of the compared groups and their perceived likeness to the individual. While high status groups will seek to preserve their superiority over 
other groups, low status groups are still found to describe their membership as displaying unique qualities that allow them to feel good about themselves. To develop these distinct positive qualities low status groups compare themselves to other groups that they feel superior to or by reframing a negative quality into something estimable (Tajfel \& Turner, 1985).

This need for groups to feel that they possess singular, positive qualities in comparison to other groups is called positive distinctiveness. Research into positive distinctiveness shows that groups tend to evaluate the status of their own group (in-group) positively compared to other groups (outgroups) with whom they have some relationship. The descriptions that we develop from our comparisons between our own and outgroups are called self-categorisations. The protection of a positive SI relies on in-groups internalising these positive self-categorisations and their negative categorisations of selected outgroups.

These principles are reflected in what Haslam (2004) refers to as the social identity approach (SIA). The SIA comprises two theories: Self-categorisation theory (SCT) focuses on aspects of identity which derive from meaningful groups to which we belong and how we set about socially defining ourselves in these important memberships (Turner, 1985). Complementing SCT, social identity theory (SIT) explains the processes by which groups and their members perceive and act towards their own membership and relevant outgroups (Tajfel, 1978). Together these theories have illuminated how SI definitions become constructed and the relational dynamics that can occur between organisational groups. SI has been shown to be more salient for employees than personal identity for explaining behaviours in organisations (Ashforth \& Mael, 1989; Hogg \& McGarty, 1990). Accordingly, SIA has enhanced the understanding of leader-group behaviour, work 
motivation, industrial conflict and responses to job and organisational changes (Haslam, 2004) through insights into the social constructions and behavioural processes by which individuals define themselves in terms of meaningful groups and in-group and inter-group relations.

If social identity explains much organisational behaviour, we might presume that there is ample evidence demonstrating that HRD initiatives are interpreted through employees' group identities. Surprisingly though, until recently little research has investigated this topic, either by SI academics or their counterparts in HRD. One reason for this is that SI research has been directed primarily at explaining how social identification affects employee and management experiences and relations, rather than exploiting SI knowledge to enhance HR policies and practices. For example, HRD practices are not given in the index of Haslam's (2004) influential book on SIA research in organisations. Nevertheless, since the publication of Haslam's book, the few articles linking SI to employee learning, development and training provide some provisional insights.

Brum's (2007) examination of the effects of training on employee commitment, for example, is in no doubt that the outcomes of HRD activity depend on the strength of trainees' identification with their organisation. Brum also concludes that trainees possessing strong sub-organisational workgroup identities may well move to protect their existing social categorisations by resisting training, change and development initiatives. Although Brum reaches this view with only slight reference to either SCT or SIT, Korte's (2007) more thorough article, examining the role of the SIA in training, agrees with and extends Brum's conclusions. Korte argues that employees' identifications usually lie in groups below the organisational level. This predominance of work-group identifications means that whether HRD is seen by employees to enhance or threaten these 8 
established categorisations will dictate which, if any, ideas and practices workers are prepared to learn and accept from the formal organisation.

Korte's claim from social identity theory that employees' acceptance of HRD is dependent on the programme tapping into local, work-group identities has been corroborated in Bjerregaard Haslam and Morton's (2016) empirical study of care-workers. Here, non-standard professionalisation training that emphasised distal work identities was associated with a reduction in work-group identification; a reduced motivation to apply the training and a drop in the level of relatedness felt by trainees during the course. By contrast, participants taking standard professionalisation training that enhanced existing, meaningful work-group identities strengthened their work-group identification; retained or increased their motivation to use the learning from the course and maintained their sense of relatedness during the training. These results suggest that even specialised, highly focused training may not improve worker performance unless existing and relevant identities of participants are harnessed by the learning approach adopted.

While Bjerregaard et al.'s findings confirm the importance of training that engages with participants' work-group identities, much HRD in practice aims to change employees by inculcating managerially defined organisational identifications. Yet, SIA theory and research suggest that where sub-organisational identities diverge from management's expectations of the formal organisation, workers are likely to ignore or resist when they see HRD activities as threatening to their current social identities. Such reactions are predicted to be especially problematic for the types of HRD emphasised by Korte and Brum that involve identity management, strategic change training and attempts to develop employee organisational 
commitment. Even functional skills and processes training may be resented by low status groups if used purely to increase worker efficiency. This is not say that different types of worker and work-group will never see HRD activities as an opportunity to advance their social identity. SIA principles underlying social mobility, for example, suggest that some workers may welcome HRD initiatives in order to become eligible to join a higher status identity group (Haslam, 2004). Equally, while management development may be welcomed, some studies show that managers too can see training as a denunciation of their current practices (Korte, 2007).

Ultimately, then, HRD efforts to alter individual workers' attitudes, loyalties or skills will likely be determined by how these attempts are seen to affect employees' group identities. As Haslam (2004) emphasises, the major barrier to employee acceptance of management changes is that workers often see managers as 'one of them'. Consequently, Kelly and Kelly's (1991) study of employee involvement projects argues that mutual understanding is only possible where efforts are made to develop more frequent contact, institutional support, relative equality in status, benefits and trust, as well as to provide employee choice over participation in developments affecting the workforce. Kelly and Kelly's findings combined with Korte's (2007) and Bjerregaard et al.'s (2016) examinations of the application of SIA to HRD offer two stark conclusions to those involved in designing HRD. First, HRD initiatives which proceed without incorporating some understanding of the organisation's group identities are likely to be seen as a threat and possibly resisted by employees. Second, while attempts to understand the social-categorisations of groups will be testing for managements, HRD practices may be most effective if designed to support or enhance work-groups' existing standing, singularity and self-assurance. 


\section{Identity Work and Human Resource Development}

Identity work, as a concept describing the 'doing' (Watson, 2008) of identity through talk and embodied performance, offers a rich set of theoretical resources for understanding HRD. The social constructionist epistemology underpinning identity work theory which conceives identity as an on-going process of becoming (Watson \& Harris, 1999) similarly informs understandings of HRD as a practice and process of becoming (Lee, 2001; Jørgensen \& Henriksen, 2011). This suggests that theoretical synergies may be fruitful for future research.

The "active 'work' which people do on their identities" (Watson, 2008, p. 124) is acknowledged in conceptualisations of identity work as an ongoing process of "forming, repairing, maintaining, strengthening or revising" self-identity constructions (Alvesson \& Willmott, 2002, p. 626; Sveningsson \& Alvesson, 2003, p. 1165). However, Watson (2008) contends that this conceptualisation over-emphasises "the self or 'internal' aspect of identity" (p. 127, emphasis in original). His alternative conceptualisation acknowledges that identity work is performed both ‘inwardly' and 'outwardly'.

Having a "clear analytical distinction between internal personal 'self-identities' and external discursive "social-identities"” (Watson, 2008, p. 121) enables appreciation of the interrelated nature of "the 'self' aspects of identity and the discourses to which they relate" (p. 127). Individuals draw upon socially available language and practices, including in the form of social-identities such as 'manager' or 'HRD practitioner', as “identity-making resources” (Watson, 2008, p. 129) in their identity work. "Prevailing discourses and local ideational notions of who people are" (McInnes \& Corlett, 2012, p. 27) inform interaction with others, and may be drawn upon, in a relatively free 
way, as resources to construct valued and distinctive self-identities and equally may be experienced, in a constraining way, delimiting how one should think and act in particular circumstances (McInnes \& Corlett, 2012). Therefore, an identity work theoretical perspective might be positioned within both interpretive and critical approaches to identity research (Alvesson, Ashcraft \& Thomas, 2008). While both approaches "assign a central role to discourse in identity processes" (Andersson, 2012, p. 573), the interpretive approach, considered in this section of the chapter, tends to view individuals as agentic (Watson, 2008; Warhurst, 2011). Individuals actively draw on and balance different and potentially competing discourses, as discursive resources or 'tools' (Andersson, 2012). They are then drawn upon to give meanings to particular socialidentities, such as manager, and incorporated, or otherwise, as 'me'/ 'not-me' positions into individuals' self-identities, as they 'story' their lives and work experiences (Sveningsson \& Alvesson, 2003; Watson, 2008).

There are ongoing debates about an over-emphasis on discursive practices in identity work theory with, for example, Down and Reveley (2009) demonstrating that self-narration and performance are used simultaneously in constructing, for instance, managerial identity. However, we focus on narrative forms of identity work because these align with theoretical understandings of identity used in HRD-related texts. For instance, in one of the few HRD textbooks we found, which dedicated a chapter to 'Identity and HRD', Jørgensen and Henriksen (2011) discuss how HRD is "closely linked to the identities of the employees and to the stories they tell" (p. 129). They develop the concept of identity as living storytelling: "Stories are living because they are becoming and are shaping our individual and communal identities and imagined futures” (Jørgensen \& Henriksen, 2011 p. 134). Although "theoretically, we might say, everyone engages in identity work" (Watson, 
2008, p. 130) all the time, identity work may be intensified when individuals: 1) engage in development programmes; 2) make job and/or career transitions and 3) experience organisational development, for instance during times of organisation re-structure. These three areas of identity work studies relate to McLagan's (1989) broadly supported understanding, according to McGuire (2011), of HRD as encompassing three foci of training and development, career development and organisational development. Therefore, we discuss how identity work research has explored these areas and consider implications for HRD practice.

\section{Identity work and development programmes}

Identity work research explores how HRD interventions such as manager/leader development programmes influence identity processes (Warhurst, 2011, 2012; Andersson, 2012). Some studies take a critical perspective and consider how management development programmes may regulate identity (Andersson, 2012). However, Warhurst (2011, 2012), who explores the contribution of MBA study to identity work, argues that "[m]anagers are more likely to engage in agentic identitywork" (Warhurst, 2011, p. 265). He discusses how a particular MBA programme provides a range of 'powerful' resources for identity work, including "linguistic resources for 'sense-making' and understanding what being a manager was 'about' ... [and] a safe forum for experimenting with provisional selves" (Warhurst, 2011, p. 275). Similarly, Caroll and Levy's (2010) ideas around leadership development as identity construction demonstrate leadership development as opportunities for working with resources, for instance in 'storying' leader identity narratives.

Linking leader/manager development and identity, therefore, is fruitful, for instance in appreciating how development programmes provide resources, tools and environments for identity 
work (Warhurst, 2011, 2012). Resources relating to identity work include social learning interactions in communities of practice (Jørgensen \& Keller, 2007; Warhurst, 2012), mentoring (Warhurst, 2012) and the 'language games' of, amongst others, HR people, consultants and development programme participants (Jørgensen \& Henriksen, 2011). Finally, in discussing the practical implications of his study, Andersson (2012, p. 586) suggests that 'buyers' of management development need to accept an ethical responsibility for 'taking care' of its influence on individuals' ongoing identity work.

\section{Identity work and job/career transitions}

Making job or career transitions, for instance when professionals are becoming managers (Watson \& Harris, 1999; Corlett, 2009), may prompt 'intensive' identity work (Sturdy, Brocklehurst, Winstanley \& Littlejohns, 2006, p. 854). When individuals proactively consider career questions such as "who do I want to become?" identity work may shape future social-identity possibilities (Andersson, 2012, p. 584). Identity work studies also consider how individuals revise their selfnarratives when making job/career transitions. Drawing upon Watson and Harris' (1999) notion of the ongoing process of 'becoming', Blenkinsopp and Stalker (2004) explore the identity work of "emergent management academics" (p. 418) as they participate in new "communities of discourse" (p. 427) when progressing from manager to management academic. From the perspective of career identity as narrative practice, agency is possible through an individual's reflexive capability to exercise choice in articulating, performing and negotiating identity positions from the multiple and contradictory positions in any given local, social and historic context (LaPointe, 2010). 
Understanding career (and occupational) identities as emergent in talk and as a process of negotiating positions in social interactions has implications for HRD practice. For instance, it highlights the importance of coaching, mentoring and other conversations as contexts for narrating future career identities. Ibarra's (2003) study, of 39 people making radical career transitions, considers how individuals craft "trial narratives" (p. 60) in reworking, revising and trying out different versions of their changing life story on others. Although Ibarra and Barbulescu's (2010) process model of narrative identity work in work role transitions may be regarded as a functionalist perspective on identity (Alvesson, Ashcraft \& Thomas, 2008), they do draw upon narrative explanations. They propose that individuals, when making discontinuous or traditionally undesirable job/career moves, draw on and adapt self-narrative repertoires in making, negotiating and achieving validation of identity claims social interactions (Ibarra \& Barbulescu, 2010). Fachin and Davel (2015) also utilise the work of Ibarra (with Petriglieri, 2010) to argue that, when future career identities are unknown, identity work combines synergistically with identity play processes of discovering and exploring future possibilities (Ibarra \& Petriglieri, 2010). They commend their framework to career counsellors and, we suggest, HRD practitioners supporting people considering radical career transitions, or those whose job/career transition is beyond their control (Fachin \& Davel, 2015). We now elaborate on the latter as part of organisational development.

\section{Identity work and organisational development}

A social constructionist understanding of organisations implies that they are always in a state of becoming, and that they - and the individuals working in them - are continuously being reconstructed, as individuals interact, communicate and negotiate meaning (Jørgensen \& Henriksen, 2011). Concerns of "organisational identity" may be experienced, at the individual 15 
level, as a "crisis of self-identity" (Blenkinsopp \& Stalker, 2004, p. 423). Organisation development, occurring in, for example, periods of economic change and/or through internal structural changes, may generate individual-level symbolic insecurity (related to, for instance, occupational identity and status) or material insecurity (related to potential job loss) (Collinson, 2003). Such insecurity may prompt conscious identity work as individuals question "What do you [the organization] want from me?", "What do I want to be in the future?" (Linstead \& Thomas, 2002, p. 1) and "Who can I be?" (p. 17). Carroll and Levy (2010, p. 214) concur that organisationcontext instability combined with self-reflexivity generates "active and even intense" identity work for individuals. In summary and in keeping with studies of organisational restructuring (c.f. Thomas \& Linstead, 2002; Pritchard, 2010) we argue that taking an identity and identity work perspective may provide new insights into HRD practices.

\section{Discourse, Identity and Human Resource Development}

Like the other approaches, the conceptual tools offered by study of discourse and identity opens up examination of the way HRD shapes, and is shaped by, those who become subject to it. This said, the complexity of the field's theoretical underpinnings and the often obscure terminology employed by its leading exponents can be discouraging. Hopefully some reassurance can be found in this - vastly simplified - review of the central ideas and main debates relevant to scholars and practitioners of HRD.

We begin with a favourite conference question; 'what do you mean when you say discourse?'. Its relevance lies not just in discourse being poorly defined, but also as people are prone to invoke the term in order to perform discourse-ness to their audience. We'll return to the circularity of this 16 
performative act later, but let us first offer a working definition of discourse as a socially recognisable movement in meaning that conveys normative ideas of the type of people we are, and the type of relations we should maintain with others. As Alvesson and Karreman (2000) explain, such movements can be understood to operate at different levels of ' $d$ '/' $D$ '-iscourse. At the big D end, so-called 'grand Discourse' refers to the movements in meaning that have shaped our understandings of ourselves and our relationship to the world. For example, the very idea of Human Resources Development might be argued to reflect the 'D'iscourse of individualism in viewing its target as isolated subjects who accumulate knowledge. There is nothing wrong with this, of course, except that it potentially brackets alternative understandings that might suggest the self is socially shaped and performed.

No less influential are those societal ideas that inform our place in the world. Gender is a prime example of what is termed Big-D Discourse with extensive scholarship recognising that prevailing norms delineating female/male, or for that matter gay/straight, emerge from particular sociohistorical conventions rather than physiological, or genetic 'realities'. This recognition has helped them to critique the inequalities which have come to accompany such dualistic categories (Linstead \& Thomas, 2002). 'Leadership' is perhaps the most familiar of the big-D Discourses for HRD scholars (Carroll \& Levy, 2010; Mabey, 2013). It is here that one can appreciate the shift in perspective studying discourse represents. Rather than investigating the skills, attributes, or even the models which should apply in a given context, discourse analysts are - at this level of analysis - interested in understanding the way in which prevailing ideas of leadership delimit who participants can become within a given context (Harding, Lee, Ford \& Learmonth, 2011). 
While 'D'iscourses operate at a societal level, they equally inform, and are informed by, discussions of what should be done, and the type of identities selves should have, within local contexts. Such meso-level discourses are often marked by divergence and multiplicity as meanings intersect with other discourses and extant discursive fields (Hardy \& Phillips, 1999). Within the HRD literature this perspective has been used to highlight tensions in the field, and to argue the need for reflexivity (Metcalfe, 2008). There remains, though, an opportunity to focus analysis upon the way discourses shape how things 'should' be done, by whom, and for whom (Davies \& Thomas, 2008). In this respect it is less the conditioning effect of a singular discourse, and more the ambiguity created by discourse(s) that proves analytically interesting (Linstead \& Thomas, 2002).

As one might sense, organisational discourse studies are often concerned with how things are discussed, and it is not unusual for researchers to confuse readers by using 'discourse' (in the sense of small-d discourse) when referring to talk-within a context, or what is being talked-about. For example, many of the articles that have looked at 'HRD discourse' are directed toward a critique of what is being discussed within the field (i.e. discourse as what is talked-about) (Walton, 2003; Callahan, 2009), rather than the effects of HRD - as a discourse - upon particular contexts (Townley, 1993).

When considering studies of small-d discourse (i.e. talk) one finds a healthy overlap between the organisational discourse and identity work literatures. The two are interrelated, borrow from each other's terminology and quite often it is no more than the point of focus that distinguishes them. Hence identity scholars might use the term 'discursive resources' when demonstrating how a 18 
particular identity or subject position was established or changed (Clarke, Brown \& Hope-Hailey, 2009). Whereas a discourse scholar might emphasise the way particular terms make-present a set of meanings (Kuhn, 2009). The study of discourse, then, has a broader remit, seeking to understand how such meanings shape who we are, and who we might become, through the subject positions discourse offers up; the spaces in which enactments can take place; the practices through which self and other become subjects; and the objects through which these positions are exercised (Hardy, 2004; Hardy \& Thomas, 2015). In short, the study of discourse concerns understanding 'the conditions of possibility' under which we become comprehensible in the social world.

The relationship of materiality to discourse has recently emerged as one of two areas of debate within the field (Hardy \& Thomas, 2015). Like the second - performativity, or specifically 'critical performativity' - (Gond, Cabantous, Harding \& Learmonth, 2015) it reflects long-standing debates concerning the extent to which we should understand the world to be discursively formed, and the extent to which agency can be exercised (Alvesson \& Karreman, 2011; Mumby, 2011). Mercifully, space prevents comprehensive coverage. However, it might help those deciding their position on these issues to question any drift to determinism by asking themselves 'in what way could it be other?'. Discourse is always open-ended, meaning is never entirely closed off (Mumby, 2011). Equally, discourse is social and while it may inform certain talk, practices and configurations of objects, this does not mean social actors act predictably. Our fictional academic who repeatedly uses the term discourse, for example, might well do so in response to the normative expectations of the Critical community for whom she/he is performing. However, there is no reason to assume that this performative enactment will see them secure a discourse researcher identity (Gond et al., 2015). 
A discourse-based view of identity offers exciting possibilities for HRD, allowing it to engage in critique, while simultaneously retaining an interest in the implications of what is included and excluded from its practice. Connecting this to the type of subject positions made possible by its practice can open up new debates on the type of subject positions made available to practitioners and those being developed through their practice.

\section{Concluding Comments}

Our brief consideration of social identity, identity work, and discourse has, we hope, provided a taste of the subtle variation in flavour offered up by social constructionist approaches to identity. In many ways the fields lean upon one another but in others they constitute distinct language games through which the social world can be understood. These standpoints on identity can inform both HResourceD and HumanRD by opening up new research trajectories at individual and organisational levels. We saw, for example, that social identity (SI) links individual level HResource D activities such as mentoring and career guidance to the group memberships which may become salient through them. While this might help 'improve' HResource D techniques, SI directs our attention away from doing so through the imposition of unitary organisational identification, and towards the dialogic approach to multiple identities suggested in HumanRD. There are, then, opportunities to research not just the conditions under which a social identity becomes salient, but also in examining how a category/categories are employed and managed as circumstances evolve. 
Similarly, Identity Work (IW) opens avenues for investigating the resources and processes through which identities are established, maintained and changed. We noted the relevance of this approach to the study of development programmes and career transitions, but it might equally enable an exploration of the way issues such as green-ness, equality or dignity - central to the HumanRD become embedded in collective and individual identities. Note, however, that neither IW nor (and especially) discourse approaches furnish the author with a straightforward standpoint to engage in humanist critique of employer practices. Discourse would, for example, recognise dignity at work as a current discourse but, as a socially constructed category, studies of discourse would contest the innate 'rightness' assumed in Human RD. Rather discourse studies provides a platform through which to critically examine the subjectivities produced through HRD practices as well as the technologies of HResourceD, such as counselling, by which they are brought into being.

\section{References}

Allameh, S. M., Naftchali, J. S., Pool, J. K. \& Davoodi, S. M. R. (2012). Human Resources Development Review according to Identity, Integration, Achievement and Adaptation Model. International Journal of Academic Research in Business and Social Sciences, 2, 42.

Alvesson, M., Ashcraft, K. L. \& Thomas, R. (2008). Identity matters: reflections on the construction of identity scholarship in organization studies. Organization, 15, 5-28.

Alvesson, M. \& Karreman, D. (2000). Varieties of discourse: On the study of organizations through discourse analysis. Human Relations, 53, 1125-1149.

Alvesson, M. \& Karreman, D. (2011). Decolonizing discourse: critical reflections on organizational discourse analysis. Human Relations, 64, 1121-1146. 
Alvesson, M. \& Willmott, H. (1996). Making sense of management: A critical introduction. London: Sage.

Alvesson, M. \& Willmott, H. (2002). Identity regulation as organizational control: producing the appropriate individual. Journal of Management Studies, 39, 619-644.

Andersson, T. (2012). Normative identity processes in managers' personal development training. Personnel Review, 41, 572-589.

Arregle, J. L., Hitt, M. A., Sirmon, D. G. \& Very, P. (2007). The development of organizational social capital: attributes of family firms. Journal of management studies, 44, 73-95.

Ashforth, B. E. \& Mael, F. (1989), Social Identity Theory and the Organization. The Academy of Management Review, 14, 20-39.

Baek, P. \& Kim, N. (2014). Exploring a theoretical foundation for HRD in society: toward a model of stakeholder-based HRD. Human Resource Development International, 17(5), 499-513.

Bjerregaard, K., Haslam, S. A. \& Morton, T. (2016), How identification facilitates effective training: the evaluation of generic versus localized professionalization training. International Journal of Training and Development, 20(1), 17-37.

Blenkinsopp, J. \& Stalker, B. (2004). Identity work in the transition from manager to management academic. Management Decision, 42, 418-429.

Brum, S. (2007). What impact does training have on employee commitment and employee turnover? University of Rhode Island. Schmidt labour research centre seminar research series. Available at http://s3.amazonaws.com/academia.edu.documents/35330794/BrumCommitment.pdf (accessed 15th June 2017)

Byrd, M. Y. (2014). Diversity Issues Exploring "Critical” Through Multiple Lenses. Advances in Developing Human Resources, 16(4), 515-528. 
Callahan, J. L. (2009). Gazing into the crystal ball: Critical HRD as a future of research in the field. Human Resource Development International, 10, 77-82.

Carroll, B. \& Levy, L. (2010). Leadership development as identity construction. Management Communication Quarterly, 24, 211-231.

Carter, V. K., Howell, S. L. \& Schied, F. M. (1999). Shaping self-disciplined workers: A study of silent power in HRD. Proceedings of the Adult Education Research Conference 1999, DeKalb, Il. Clarke, C. A., Brown, A. D. \& Hope-Hailey, V. (2009). Working identities? Antagonistic discursive resources and managerial identity. Human Relations, 62, 323-352.

Collins, J.C., McFadden, C., Rocco, T.S. \& Mathis, M.K. (2015). The problem of transgender marginalization and exclusion: Critical actions for Human Resource Development. Human Resource Development Review, 14, 205-226.

Collinson, D. L. (2003). Identities and insecurities: selves at work. Organization, 10, 527-547.

Corlett, S. (2009). Professionals becoming managers: Personal predicaments, vulnerability and identity work. Newcastle upon Tyne: Northumbria University.

Day, D. V. \& Harrison, M. M. (2007). A multilevel, identity - based approach to leadership development. Human Resource Management Review, 17, 360-373.

Davies, A. \& Thomas, R. (2008). Dixon of Dock Green got shot! Policing identity work and organizational change. Public Administration, 86, 627-642.

Devadas, U. M., Silong, A. D. \& Krauss, S. E. (2011). Human resource development and the contemporary challenges of the world. Journal of Management Policy and Practice, 12, 128.

Down, S. \& Reveley, J. (2009). Between narration and interaction: Situating first-line supervisor identity work. Human Relations, 62, 379-401. 
Fachin, F.F. \& Davel, E. (2015). Reconciling contradictory paths: Identity play and work in a career transition. Journal of Organizational Change Management, 28, 369-392.

Fenwick T. (2004) Toward a Critical HRD in Theory and Practice. Adult Education Quarterly. 54(3), 193-209.

Fenwick, T. (2005). Conceptions of Critical HRD: Dilemmas for Theory and Practice. Human Resource Development International, 8(2), 225-238.

Garrick, J. (1998) Informal Development in the Workplace: unmasking human resource development. London: Routledge.

Gedro, J., Collins, J. C. \& Rocco, T. S. (2014). The "Critical” Turn an Important Imperative for Human Resource Development. Advances in Developing Human Resources, 16(4), 529-535.

Giddens, A. (1991). Modernity and self-identity: Self and society in the late modern age. Stanford University Press.

Gond, J.-P., Cabantous, L., Harding, N. \& Learmonth, M. (2015). What do we mean by performativity in Organizational and Management Theory? The uses and abuses of performativity. International Journal of Management Reviews, DOI: 10.1111/ijmr.12074.

Harding, N., Lee, H., Ford, J. \& Learmonth, M. (2011). Leadership and charisma: A desire that cannot speak its name? Human Relations, 64, 927-949.

Hardy, C. (2004). Scaling up and bearing down in Discourse Analysis: Questions regarding textual agencies and their context. Organization, 11, 415-425.

Hardy, C. \& Phillips, N. (1999). No joking matter: Discursive struggle in the Canadian refugee system. Organization Studies, 20, 1-24.

Hardy, C. \& Thomas, R. (2015). Discourse in a material world. Journal of Management Studies, $52,680-696$. 
Haslam, S. A. (2004). Psychology in organizations: The social identity approach (2nd ed.). London: Sage.

Hogg, M. A. \& McGarty, C. (1990). Self-categorization and social identity. In D. Abrams \& M. A. Hogg (Eds.), Social identity theory: Constructive and critical advances (pp. 10-27). London: Harvester Wheatsheaf.

Holton, E. F. \& Yamkovenko, B. (2008). Strategic intellectual capital development: a defining paradigm for HRD? Human Resource Development Review, 7(3), 270-291.

Hoyer, P. \& Steyaert, C. (2015). Narrative identity construction in times of career change: Taking note of unconscious desires. Human Relations, 68(12), 1837-1863. doi: 0018726715570383.

Ibarra, H. (2003). Working identity: Unconventional strategies for reinventing your career. Boston, MA: Harvard Business School.

Ibarra, H. \& Barbulescu, R. (2010). Identity as narrative: Prevalence, effectiveness, and consequences of narrative identity work in macro role transition. Academy of Management Review, $35,135-154$.

Ibarra, H. \& Petriglieri, J. L. (2010). Identity work and play. Journal of Organizational Change Management, 23, 10-25.

Johnsen, R. And Gudmand-Høyer, Marius (2010). Lacan and the lack of humanity in HRM. Organization, 17, 331-344.

Jørgensen, K. M. \& Henriksen, L. B. (2011). Identity and HRD. In D. McGuire and K. M. Jørgensen (Eds.), Human Resource Development: Theory and practice (pp.129-140). London: SAGE Publications Ltd.

Jørgensen, K. M. \& Keller, H. D. (2007). Learning as negotiating identities, Aalborg: Institut for Uddanneise, Læring og Filosofi, Aalborg Universitet. 
Kelly, J. \& Kelly, C. (1991). "Them and us": social psychology and the "new industrial relations". British Journal of Industrial Relations, 29, 25-48.

Korte, R. F. (2007). A review of social identity theory with implications for training and development. Journal of European Industrial Training, 31, 166-180.

Kuhn, T. (2009). Positioning lawyers: Discursive resources, professional ethics and identification. Organization, 16, 681-704.

LaPointe, K. (2010). Narrating career, positioning identity: Career identity as a narrative practice. Journal of Vocational Behavior, 77, 1-9.

Lee, M. (2001). A refusal to define HRD. Human Resource Development International, 4, $327-$ 341.

Linstead, A. \& Thomas, R. (2002). "What do you want from me?": a poststructuralist feminist reading of middle managers' identities. Culture and Organization, 8, 1-20.

Luthans, F., Vogelgesang, G. R. \& Lester, P. B. (2006). Developing the psychological capital of resiliency. Human Resource Development Review, 5(1), 25-44.

Mabey, C. (2013). Leadership development in organizations: Multiple discourses and diverse practice. International Journal of Management Reviews, 15, 359-380.

McGuire, D. (2011). Foundations of Human Resource Development. In D. McGuire and K. Jøregensen (Eds.), Human Resource Development: Theory and practice (pp.1-11). London: SAGE Publications Ltd.

McGuire, D. (2014). Human Resource Development: Theory and Practice. 2nd Ed. London: Sage. McGuire, D. \& Garavan, T. N. (2013). Reclaiming the "D" in HRD. Proceedings of the 2013 UFHRD. 
McGuire, D., Garavan, T. N., O'Donnell, D. \& Watson, S. (2007). Metaperspectives and HRD: Lessons for research and practice. Advances in Developing Human Resources, 9, 120-139. McInnes, P. \& Corlett, S. (2012). Conversational identity work in everyday interaction. Scandinavian Journal of Management, 28, 27-38.

McLagan, P. (1989). Models for HRD practice. Alexandria, VA: American Society for Training and Development Press.

Metcalfe, B. D. (2008). A feminist poststructuralist analysis of HRD: Why bodies, power and reflexivity matter. Human Resource Development International, 11, 447-463.

Muir, D. (2014). Mentoring and Leader Identity Development: A Case Study. Human Resource Development Quarterly, 25, 169-186.

Mumby, D. K. (2011). What's cooking in organizational discourse studies? A response to Alvesson and Karreman. Human Relations, 64, 1147-1161.

Nordenfelt, L. (2004). The varieties of dignity. Health care analysis, 12, 69-81.

Oakes, P. J. (1987). 'The salience of social categories', in J.C. Turner, M. A. Hogg, P. J. Oakes, Reicher, S. D. \& Wetherell, M. S. (Eds.), Rediscovering the Social Group: A Self-categorization Theory, (pp.117-141). Oxford: Blackwell.

Perriton, L. (2005). Sense or sensibility? A reflection on virtue and 'emotional' HRD interventions. Critical thinking in human resource development, 175-188.

Pritchard, K. (2010). Becoming an HR strategic partner: tales of transition. Human Resource Management Journal, 20, 175-188.

Riach, K. \& Loretto, W. (2009). Identity work and the 'unemployed' worker: age, disability and the lived experience of the older unemployed. Work, Employment \& Society, 23, 102-119. 
Scully-Russ, E. (2015). The Contours of Green Human Resource Development. Advances in Developing Human Resources, 17, 411-425.

Sturdy, A., Brocklehurst, M., Winstanley, D. \& Littlejohns, M. (2006). Management as a (self) confidence trick: Management ideas, education and identity work. Organization, 13, 841-860.

Sveningsson, S. \& Alvesson, M. (2003). Managing managerial identities: organizational fragmentation, discourse and identity struggle. Human Relations, 56, 1163-1193.

Tajfel, H. (1978). Differentiation Between Social Groups: Studies in the Social Psychology of Intergroup Relations, London: Academic Press.

Tajfel, H. \& Turner, J.C. (1985). The social identity theory of intergroup behaviour. In S. Worchel and W.G. Austin (Eds.), The psychology of intergroup behaviour ( $2^{\text {nd }}$ ed., pp.7-24). Chicago: Nelson-Hall.

Thomas, R. \& Linstead, A. (2002). Losing the plot? Middle managers and identity. Organization, 9, 71-93.

Townley, B. (1993). Foucault, power/knowledge, and its relevance for human resource management. Academy of Management Review, 18, 518-545.

Turner, J. C. (1985). 'Social categorization and the self-concept: a social cognitive theory of group behaviour', in E. J. Lawler (Ed.), Advances in Group Processes (vol2, pp.77-122). Greenwich, CT: JAI press.

Walton, J. S. (2003). How shall a thing be called? An argumentation on the efficacy of the term HRD. Human Resource Development Review, 2, 310-326.

Warhurst, R. (2011). Managers' practice and managers' learning as identity formation: Reassessing the MBA contribution. Management Learning, 42, 261-278. 
Warhurst, R. (2012). Leadership development as identity formation: middle managers' leadership learning from MBA study. Human Resource Development International, 15, 471-487.

Watson, T. J. (2008). Managing identity: identity work, personal predicaments and structural circumstances. Organization, 15, 121-143.

Watson, T. J. \& Harris, P. (1999). The emergent manager. London: Sage. 